\title{
IFToMM Terminology Commission and Standardization of Mechanism and Machine Science Terminology
}

\begin{abstract}
Štefan Segl'a
Professor

Technical University of Košice Faculty of Mechanical Engineering Košice, Slovakia
\end{abstract}

Nearly forty five years ago the Permanent Commission for the Standardization of Terminology of the International Federation for the Promotion of Mechanism and Machine Science (IFToMM) was founded. Since then the commission underwent a successful development and worked out recognized terminological documents in printed and also electronic form. The paper deals with history of the commission from its early days, activities, methodological aspects and important achievements. In the course of time from 1969 to 2014 nearly sixty scientists from twenty five countries were involved in the commission.

Keywords: Terminology, dictionary, mechanism and machine science, history, methodology.

\section{INTRODUCTION}

According to the Constitution and By Laws of the International Federation for the Promotion of Mechanism and Machine Science (IFToMM) the aim of the Permanent Commission for the Standardization of Terminology (Commission A) is:

- to write a standard terminology (with definitions) for Mechanism and Machine Science, including terms pertaining to the realization of motion and its control, associated problems in dynamics and kinematics, and in machine components,

- to cooperate with other international and national bodies concerned with terminology and related matters.

As for the the Mechanism and Machine Science itself, this is defined as: "Branch of science, which deals with the theory and practice of the geometry, motion, dynamics and control of machines, mechanisms and elements and systems thereof, together with their application in industry and other contexts, e.g. in biomechanics and the environment. Related processes, such as the conversion and transfer of energy and information, also pertain to this field."

The constituent meeting of the Commission A took place on September 18, 1971, in Kupari, Yugoslavia. The Commission A started with five paticipants and is still active now with twenty five persons from 18 countries.

Unification of terminology at the international level became important for teaching, communication and also for research associated with the development of new and rapidly developing fields of science and engineering, e.g. mechatronics, micro- and nanomechanisms, biomechanisms, compliant mechanisms etc.

Received: May 2014, Accepted: May 2014

Correspondence to: Štefan Segl'a

Technical University of Košice,

Faculty of Mechanical Engineering, Košice, Slovakia

E-mail: stefan.segla@tuke.sk

doi:10.5937/fmet1403177S

(C) Faculty of Mechanical Engineering, Belgrade. All rights reserved
Working meetings of the Commission A bring closer together scientists of different languages and cultures and in this way international terminological work does not only have scientific significance.

\section{THE DEVELOPMENT OF THE COMMISSION A}

During the Inaugural Assembly of IFToMM on September 27, 1969, in Zakopane (Poland) the first Executive Council (EC) of the Federation was elected. Acad. prof. I. I. Artobolevskiy (Soviet Union) President, prof. F. R. E. Crossley (USA) - VicePresident, Dr. M. S. Konstantinov (Bulgaria) Secretary General, Dr. W. Thomas (Germany) Treasurer, as ordinary members: Prof. J. Oderfeld (Poland), prof. M. M. Belgaumkar (India), prof. K. Hunt (Austria). Aside from four other Permanent Commissions the EC established the Permanent Commission for Standardization of Terminology and designated prof. Muster (USA) to be chairman and prof. N. I. Levitskiy (Soviet Union) to be vice-chairman.

In the first work programme for the Commission A in 1970, Prof. Muster intended to contact the ISO Technical Committee TC 10/CS 4 in order to coordinate the mutual cooperation and objectives, over collaboration in the commission, and to summon its constituent meeting on the occasion of the $3^{\text {rd }}$ IFToMM World Congress on the Theory of Machines and Mechanisms (TMM) in Yugoslavia. The meeting was hosted by prof. Todor Pantelic (University of Belgrade) and held on September 18, 1971, in Kupari near Dubrovnik [1]. Participants were professors Bianchi (Italy), Bazjanac (Yugoslavia), Bögelsack (DDR), Davies (UK), Keller (Germany). Chairman prof. Muster and vice-chairman Prof. Levitskiy could not be present, the meeting was chaired by prof. Davies and Prof. Bögelsack, and a provisional programme with responsibilities and a set of rules were established.

As a rule, members of the Commission A meet every two years (with several exceptions) at different locations in different European countries and in this way they were offered a lot of opportunities to get to know other countries, cultures and universities. That was an 
important factor increasing efficiency of work and forming friendship, helpfulness and consideration between the colleagues.

The Chronicle of the Commission working meetings is as follows:

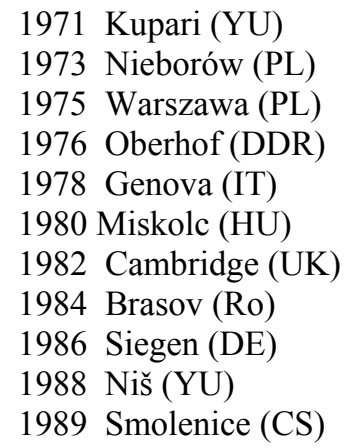

The next working meeting is scheduled for 2014 in Saint-Petersbug (RU).

Additional brief working meetings were held during

SYROM Conferences 1977, 1981, 1985 (Bucuresti, RO),

and IFToMM World Congresses

$$
\begin{aligned}
& 1987 \text { - Sevilla (ES), } \\
& 1991 \text { - Praha (CS), } \\
& 1995 \text { - Milano (IT), } \\
& 1999 \text { - Oulu (FI), } \\
& 2004 \text { - Tianjin (CN), } \\
& 2007 \text { - Besancon (FR), } \\
& 2011 \text { - Guanajuato (MX). }
\end{aligned}
$$

Between the working meetings the activity of the Commission A is run in subcommissions of specialists, structured in the fields of interest. Nowadays, the following subcommissions are operating:

- Structure and Kinematics,

- Dynamics,

- Robotics, Machine Control and Measurements,

- Mechatronics,

- Biomechanics,

- Micro- and Nanomechanisms,

- Gearing,

- Compliant Mechanisms,

- New Ordering System,

- Transportation,

- Electronic Dictionary.

\section{PUBLISHED WORK}

Initially, a master version in English language was set up and published in the IFToMM Journal Mechanism and Machine Theory [2] by a team chaired by Prof. Bögelsack. After worthwhile comments and proposals were incorporated into the subsequent draft, a fourlanguage (English, French, German, Russian - official IFToMM languages) dictionary, containing 763 terms and their definitions, resulted and was then published again in the IFToMM Journal Mechanism and Machine Theory [3] by a team chaired by Prof. T. Leinonen. It was structured into chapters and subchapters, reflecting the natural divisions of the (classic) MMS:

1. Structure of Machines and Mechanisms (Components, Sub-assemblies, Mechanisms),

2. Kinematics (General, Motion, Kinematic Geometry

3. Dynamics (General, Force and Moment, Momentum, Energy, Work and Power, Principles, Structural Behaviour and Characteristics, Structural Concepts, Dynamical Concepts, Dynamical Systems and Characteristics, Vibrations,

4. Machine Controls and Measurement (Signals and Functions, Accuracy and Errors, Devices and Components,

5. Robotics (Systems, Components, Motion, Control, Miscellaneous,

6. Appendix (General Terms used in TMM).

As a continuation, a standard set of "Abbreviations / Symbols for Terms in TMM" and "Graphical Symbols for the Representation of Mechanisms" was published in the IFToMM Journal Mechanism and Machine Theory [4].

Cooperation inside IFToMM, e.g. with Technical Committee (TC) for Nonlinear Oscillations and TC for Gearing was established with remarkable results. As well, many specialists outside the Commission A were consulted. Work on the enhancement of MMS terminology continued in two directions: updating and enriching the existing chapters as well as adding new specialized sections, such as Nonlinear Oscillations, Biomechanics, Mechatronics, Rotor Dynamics, Gearing, Stability and others. The activity also aimed at:

o facilitating the adoption of new terms and their insertion among the existing ones, with minimum reworking of numbering and indexes,

o permitting independent, modular enhancement of any section/chapter of terminology,

o increasing reader accessibility to terms and definitions,

o making the terminology more user-friendly and usable for extensive application.

The $3^{\text {rd }}$ edition of the MMS terminology appeared in the IFToMM Journal Mechanism and Machine Theory [5]. This last printed edition contains a "basic core" of 771 terms and definitions in the four official IFToMM languages and a "Supplement" of 823 terms and definitions in English obtained by developing the existing and new MMS subdomains mentioned above.

\subsection{Four-language dictionary - electronic version}

About ten years ago the Commission A started the development of an electronic version of the fourlanguage dictionary (see: www.iftomm.3me.tudelft.nl ). It was agreed that the functionality of the electronic version should be about the same as that of the printed book, but with additional browsing by means of links in the alphabetic index part and in the explanation part. 
During developing electronic version of the MMS dictionary it was also recognized that terminology is subject to discussion, extension and modification almost permanently. This lead to the decission to create the electronic dictionary automatically by a computer program, starting from the commission's working documents (text editor Word) as input. Consulting a software specialist a program structure was developed. To be prepared for more languages, a set of bi-lingual dictionaries with all possible combinations was aimed. The final product is thus a set of dictionary files (CMMfiles or compiled HTML files) for each pair of four official IFToMM languages. Certain rules of editing the Word files were needed then and the commission members had to work very accurate according to these rules. To make use of generally available software (like here the HTML-help compiler) an intermediate conversion to XML-textfiles was beneficious.

Based on such an internet dictionary it is possible to have a discussion platform regarding the terminology for the whole IFToMM community. The role of the Commission A can now be a platform of experts in terminology.

The present electronic version of the MMS terminology was restructured and contains 16 chapters:

0 . General

1. Structure of Machines and Mechanisms

1.1. Components

1.2. Sub-assemblies

1.3. Mechanisms

2. Kinematics

2.1. General

2.2. Motion (Quantities, States)

2.3. Kinematic Geometry

3. Dynamics

3.1. General

3.2. Force and Moment

3.3. Momentum, Energy, Work and Power

3.4. Principles

3.5. Structural Behaviour and Characteristics

3.6. Structural Concepts

3.7. Dynamical Concepts

3.8. Dynamical Systems and Characteristics

3.9. Vibrations

4. Machine Controls and Measurement

4.1 Signals and Functions

4.2 Accuracy and Errors

4.3 Devices and Components

5. Robotics

5.1 Systems

5.2 Components

5.3 Motion

5.4 Control

5.5 Miscellaneous

6. General Terms

7. Dynamics, Supplement

8. Rotor Dynamics and Measurement

9. Vibrations and Non-linear Oscillations

10. Stability

11. Biomechanics

11.1 General

11.2 Generation of Motion and Force

11.3 Transmission of Motion and Force
11.4 Movement of Body and Body Parts

11.5 Situation and Orientation in Body

12. Gearing

12.1 Gear and Tooth Geometry

12.2 Gear Pair Basics

12.3 Gear Pair with Parallel Axes

12.4 Gear Pair with Intersecting Axes

12.5 Crossed Axes Gear Pair

12.6 Geared Mechanisms

13. Mechatronics

13.1 Specific Fields of Work

13.2 Systems and Devices

13.3 Properties and Behaviour

14. Transportation Machinery and Logistics

14.1 General Terms and Transport Motions

14.2 Hoisting and Lifting Equipment

14.3 Belts and Conveyors

14.4 Vehicle Science

14.5 Transportational Logistics

15. Compliant Mechanisms

Nearly 60 scientists from 25 countries have been directly involved in the work of the Commission A up to 2014. Besides them many others were working on the national level. In some countries the MMS terminology was translated into the respective national language, e.g. in Japan, China, Romania, the Czech Republic and Poland.

\section{METHODOLOGY}

Unifying of terminology primarily has to have an analytical character - to select terms existing in established fields, to keep proven ones and to define them in order to make possible comparison of different systems or methods. The main work in terminology is classification and definition. Both of them are standing in a certain interrelation as either presumption or result of a terminological process. Even at the stage of setting up the list of terms to be defined, the rules of classification derived from the predicative logic are to be considered [6], [7]:

- the extent of a superordinated term should be equal to the extents of its subordinated terms,

- extents of subordinated terms should not intersect each other, they have to be disjunct,

- use of different characteristics in the same classification is allowed only if the conditions mentioned above are observed,

- subordinated terms of a certain order have to be on the same level and may not be subordinated to others,

- division into a term and its negation should be avoided (e.g. "uniform motion" and "nonuniform motion"),

- the choice of distinctive characteristics should be determined by the purpose of objects to be classified (important in new fields).

Definitions have to express what an object is, what it is serving for, how it is originated, how it can be proved. Terms in MMS belong to different categories: systems, quantities, states, phenomena, principles, operations, problems, techniques. Therefore different kinds of 
definitions are to be applied, sometimes in combination with one another [7]. For example quantities are to be defined preferebly in the physical way, not operational. For instance, "acceleration" is "rate of change of velocity with respect to time", not "derivative of velocity ...".

In view of the demand that a well-made definition should distinguish by identifying and identify by distinguishing, the Commission A reached an agreement on the following rules to be observed in the methodology of defining:

0 in each context, it must be possible to replace the term to be defined (definiendum) by the definition (definiens),

o a definition may neither contain nor cause logic contradiction,

0 the term to be defined may not appear in the definition either openly or as concealed (circular definition)

0 the predicate of a definition should not be negative,

0 definiendum and definiens must be identical in extent,

o a term should be neither overdefined (more characteristics in the definition than in the term) nor underdefined.

Some more guidelines were proposed by Prof. Prentis [8]:

o terms should be elegantly defined in the simplest possible language,

o definitions should be concise,

o terms should not be needlessly multiplied, e.g. $($ common adjective $)+($ old term $)=($ new term $)$,

o terms should not be included (or, even worse, invented) simply to provide a counter-point to other terms,

o a term that is easier to understand, than the definition should be deleted unless a simpler definition can be found,

o when in doubt, leave it out!

\section{CONCLUSION}

The Commission A must be able to develop its activity in a continuous and efficient way. This implies organizational and structural measures promoting creative work, an activity plan with tasks for each subcommission and for every member, responsibilities, schedules, cooperation, etc.

The MMS terminology is historical in character, similarly to MMS itself. It reflects a certain stage of existence and technical and scientific evolution.

Terminology must also be viewed as a science, with a profound historical pattern.

Assembling experts from countries in four continents the Commission A has a high degree of internationality. It is characterized by team spirit and fellow-like behaviour demonstrated all years of its existence.

This paper is also an invitation towards the entire MMS community at large, within and out of IFToMM, to join the future efforts of the Commission A and serve the scientific and engineering world community.

\section{ACKNOWLEDGMENT}

This work was supported by grant project VEGA No. $1 / 1205 / 12$.

\section{REFERENCES}

[1] Veg, A.: Todor Pantelić (1923-1999), in: Distinguished Figures in Mechanism \& Machine Science: Their Contributions \& Legacies, Part 2 (History of Mechanism and Machine Science) (Volume 7), Marco Ceccarelli (Editor), Springer, pp. 199-217, 2012.

[2] IFToMM Commission A, Terminology for the Theory of Machines and Mechanisms, Mechanism and Machine Theory, Vol. 18, No. 6, pp. 379-407, 1983.

[3] IFToMM Commission A, Terminology for the Theory of Machines and Mechanisms, Mechanism and Machine Theory, Vol. 26, No. 5, pp. 435-539, 1991.

[4] IFToMM Commission A, Abbreviations / Symbols for Terms in TMM, Mechanism and Machine Theory, Vol. 32, No. 6, pp. 641-666, 1997.

[5] IFToMM Commission A, Terminology for the Mechanism and Machine Science, Mechanism and Machine Theory, Vol. 38, Nos. 7-10, pp. 598-1111, 2003.

[6] Segeth, W.: Elementare Logik, Deutscher verlag der Wissenschaften, Berlin, 1972.

[7] Bögelsack, G.: Zur Terminologischen Arbeit für die Theorie der Maschinen und Mechanismen (TMM), Mechanism and Machine Theory, Vol. 17, No. 1, pp. 85-93, 1982.

[8] Prentis, J.M.: Guidelines for Terms and Definitions, in: Protocol Minutes of the Eleventh Meeting of IFToMM Commission A, Smolenice, 1989.

\section{КОМИСИЈА ИФТОММА ЗА ТЕРМИНОЛОГИЈУ И СТАНДАРДИЗАЦИЈУ ТЕРМИНОЛОГИЈЕ ИЗ ОБЛАСТИ ТЕОРИЈЕ МАШИНА И МЕХАНИЗАМА}

\section{Штефан Сегл'а}

Стална Комисија за стандардизацију терминологије Међународне федерације за промоцију теорије машина и механизама (IFToMM) основана је готово пре четрдесет и пет година. Од тог времена Комисија се успешно развијала и израдила је документа, прихваћена у области терминологије, у штампаној и електронској форми. Овај рад се бави историјом рада Комисије од оснивања, њеним активностима, методолошким аспектима и значајним постигнућима. У периоду од 1969 - 2014. године готово шездесет научника из двадесет и пет земаља је учествовало у раду Комисије. 